\title{
The identity of the nomen dubium Penaincisalia patagonaevaga Johnson, 1990 (Lepidoptera: Lycaenidae, Polyommatinae)
}

\author{
Zs. BÁLINT $^{1} \&$ D. BENYAMINI ${ }^{2}$ \\ ${ }^{1}$ Zsolt Bálint, Hungarian Natural History Museum, Department of Zoology, H-1088 Budapest, Baross utca 13, \\ Hungary.E-mail: balint.zsolt@,nhmus.hu \\ ${ }^{2}$ Dubi Benyamini, 4D MicroRobotics, 91 Levona Street, Bet Arye, 7194700, Israel. E-mail: \\ dubiben@netvision.net.il
}

\begin{abstract}
The holotype of Penaincisalia patagonaevaga Johnson, 1990 (type locality: Argentina, prov, Chubut, $40 \mathrm{~km} \mathrm{~N}$ of Rio Mayo) is a chimeric specimen as it is composed of parts belonging to two different species: the neotropical Penaincisalia penai Johnson, 1990 (forewings, genitalia) and the oriental Orthomiella rantaziana Wileman, 1910 (hindwings) or one of its relatives. For an unambiguous identity the hindwings are excluded from the holotype, resulting the new synonymy $P$. pena $i=$ P. patagonaevaga. The specimen is considered to be mislabelled because the genus Penaincisalia Johnson, 1990 (type species: Thecla culminicola Staudinger, 1894) is confined to the high Andean puna and is highly improbable that any of its representatives occurs in Patagonia.
\end{abstract}

Keywords. Chimera, patagonaevaga holotype, mislabelling, Penaincisalia, Orthomiella.

\section{INTRODUCTION}

A mongst Neotropical Lycaenidae chimeric holotypes posed several nomenclatural and taxonomic problems (see Robbins \& Lamas 2002). Some of these problems could not be solved, because their holotype specimens were not available for study and remained to be clarified (Benyamini et al. 2020). In this paper we report on a case, when the holotype specimen has been successfully located, and the identity of the nominal taxon could be revised.

\section{Penaincislia patagonaevaga Johnson, 1990 a synonym of $P$. penai Johnson, 1990}

(Figure 1)

Penaincisalia patagonaevaga Johnson, 1990: 117 Figs $3 \mathrm{~F}$ (holotype recto, and verso photographic documentation in halftone), $6 \mathrm{E}$ (holotype genitalia drawing); Johnson 1992: 164, Figs 82 (holotype genitalia drawing), 177 (holotype recto and verso photo- graphic documentation in halftone); Peña \& Ugarte 1997: 224 (artistic image of holotype recto and verso in colour; Robbins 2004b: 122 (as nomen dubium). Penaincisalia penai Johnson, 1990: 118; Robbins 2004b: 122; Prieto 2008: 99. (= P. patagonaevaga Johnson, 1990, syn. nov.)

Remarks. According to the original description $P$. patagonaevaga was described on the basis of the holotype male, deposited in the "CECUC" (= Central Entomological Collection of the University of Chile), with data: "Argentina, $40 \mathrm{~km} \mathrm{~N}$ Rio Mayo, Chubut Prov. (Patagonia), 20 Nov 1966, nr 700 m, J. Herrera" (Johnson 1990, Fig. 1a-c). As the species has been illustrated in the book „Las Mariposas de Chile", the holotype was certainly in the hands of one of the illustrators. The holotype specimen has been considered to be lost as the depositor "CECUC" does not exist and the specimen could not be located. Most probably this was one of the reasons, why the name has been regarded as nomen dubium by Robbins (2004b).

Very recently, the holotype of $P$. patagonaevaga has been found in the private collection of 

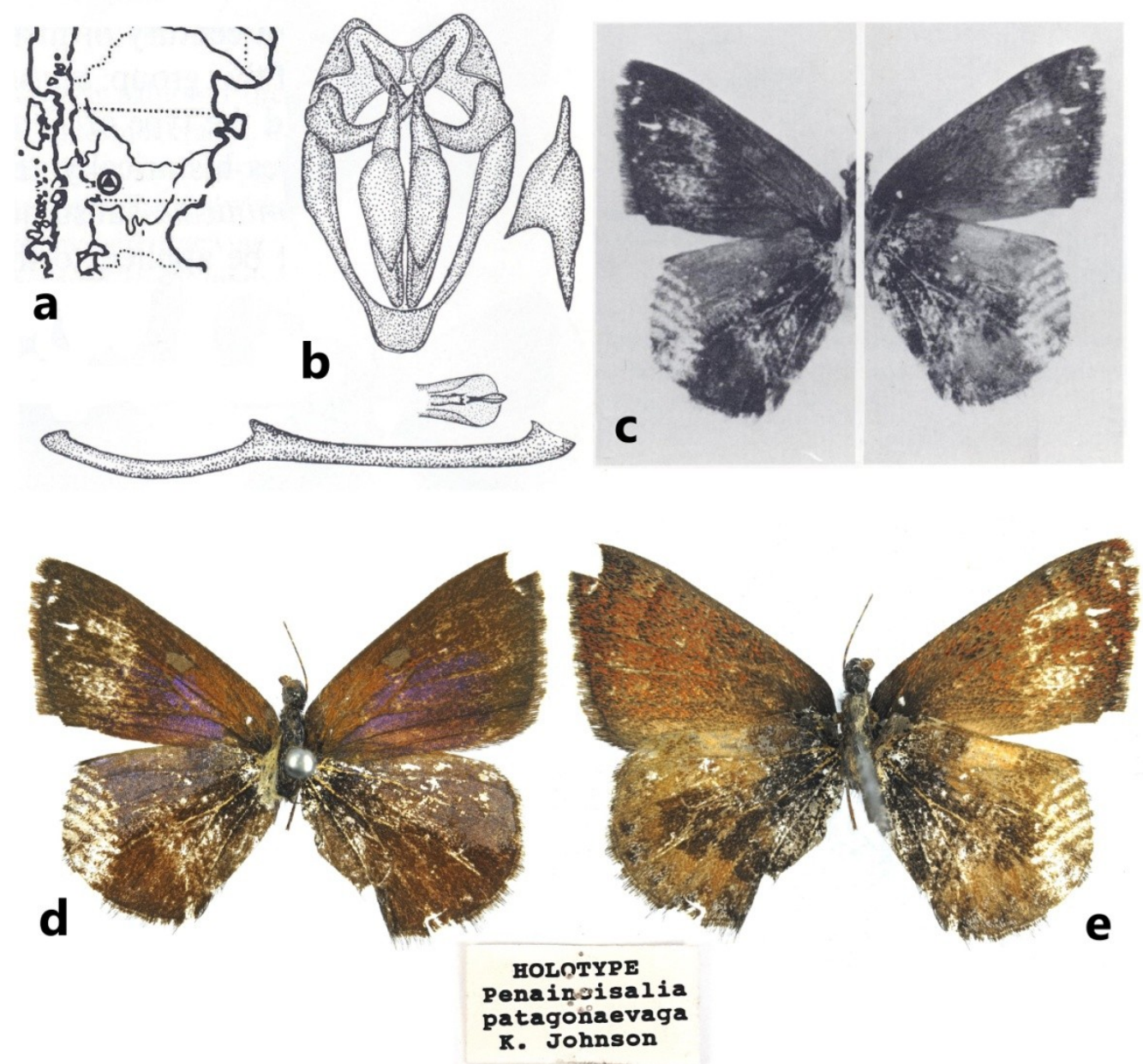

Figure 1. Penanincisalia patagonaevaga Johnson, 1990, holotype. Documentation of the original description $(\mathrm{a}-\mathrm{c})$ : $\mathrm{a}=$ indication of the type locality (Chubut, Argentina); $b=$ genitalia organ, $c=$ dissected holotype specimen, left: recto, right: verso (forewing costa length $=22 \mathrm{~mm}$ ). Documentation of the holotype specimen in colour (d-e; courtesy Marcelo Guerrero), $\mathrm{d}=$ recto, $\mathrm{e}=$ verso, and the type label (in middle).

Pedro Vidal, Santiago de Chile (ex collection Luis Peña). The specimen turned out to be a chimera as the forewings and the hindwings belong to different species (Figs. 1d-e): The dorsal surface of the forewing possess androconia typical for the Penaincisalia genus-group; there is a scent pad in the distal corner of the discal cell and a minute scent patch at the base of vein M3 (Bálint \& Wojtusiak 2006, Prieto 2008). The rufous ventral wing surface colouration suggests that the fore wings represent the species $P$. penai Johnson, 1990 (Prieto 2008). The dorsal surface of hindwing area between the costa and vein M3 has a structural blue colouration. This trait can be found in certain calycopidine hairstreaks (cf. "Thecla (? Calystryma) cissusa" in d"Abrera 1995) but in cissusa the hindwing costa is slightly bent and the ventral surface of the wing has a simple typical hairstreak pattern with median line and tornal "Thecla spot". The hindwings represent the species group of Orthomiella rantaizana Wileman, 1910, an oriental polyommatine species (d'Abrera 1986: 637), which has hindwings identical with those of the $P$. patagonaevaga holotype: hindwing shape with straight costa, dorsal wingsurface colouration between costa and vein M3 is structural blue and ventral wing surface pattern with dark median maculation (see Fig. 2). The male 

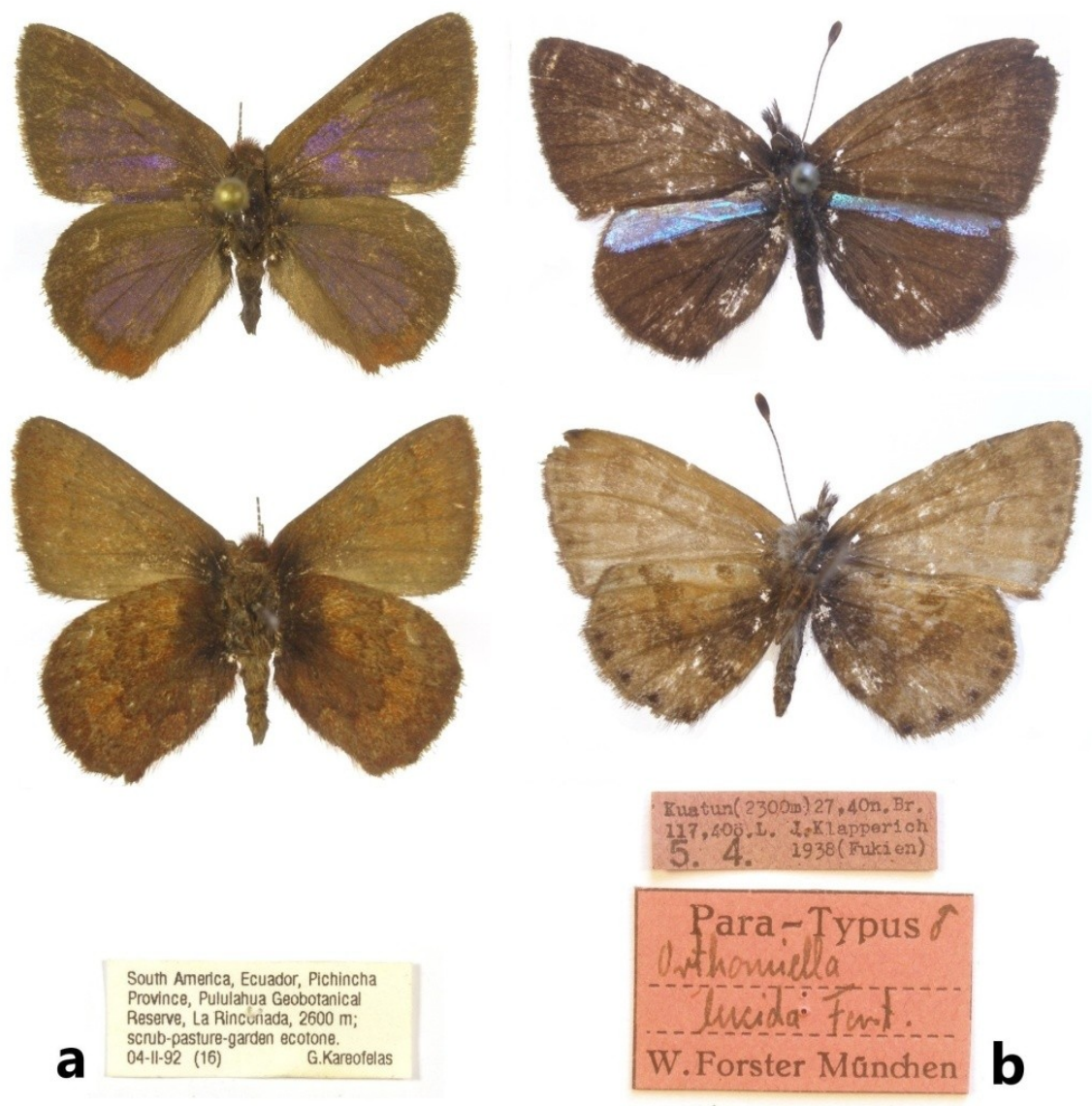

Figure 2. Hungarian Natural History Museum male specimens with their labels of lycaenid butterfly species composing the chimeric holotype Penaincisalia patagonaevaga Johnson, 1990: a = Penaicisalia penai Johnson, 1990; $\mathrm{b}=$ Orthomiella lucida Forster, 1942 (in same size; forewing costa length of $P$. penai $=12 \mathrm{~mm}$ ).

genital organ appears to represent $P$. penai (Prieto 2008), so the dissected abdomen most probably belonged to the specimen provided the holotype forewings.

Under the Article 73.1.5. of the International Code of Zoological Nomenclature (1999), the hindwings of the holotype are excluded from the $P$. patagonaevaga holotype with the taxonomic purpose of best clarifying identification of the name; consequently Penaincisalia patagonaevaga Johnson, 1990 represents a new synonym of Penaincisalia penai Johnson, 1990,

\section{DISCUSSION}

Page priority. The species-group name patagonaevaga has page priority over penai. As First Reviewers we keep the latter name, because it was listed in Robbins (2004b) as valid, while $p a-$ tagonaevaga was considered to be doubtful. Prieto (2008) followed Robbins, described and fully documented Penaincisalia penai.

Type locality. In the specimen's pin there is the characteristic holotype label of Kurt Johnson, that is usually a type-written tag (Fig. 1). However, the locality label, mentioned in the original description, is missing. The elfin hairstreaks Penaincisalia are typical species of the high Andean puna and distributed from Colombia via Ecuador, Peru and Bolivia to the Chilean-Argentina border (Prieto 2008, Bálint et al. 2019). It is highly improbable, that any of the representatives of the genus occurs in Patagonia. Therefore we consider the holotype of $P$. patagonaevaga also as mislabelled specimen, and the type locality to be erroneous. 
Johnson's neotropical Lycaenidae type problems. Robbins and Lamas (2002) identified the problems induced by the Lycaenidae types of Kurt Johnson. They documented that seven holotypes were composed of parts belonging to more than one species (Decussata colombiana Johnson, Austin, Le Crom \& Salazar, 1997; Ignata illepida Johnson, 1992; Strymon andrewi Johnson, \& Matusik, 1988; Strymon nivix Johnson, Eisele \& MacPherson, 1990; Tmolus victoria Johnson \& Matusik, 1989; Trochusinus elizabetha Salazar, Vélez \& Johnson, 1997; and Zigirina minutia Johnson \& Adams, 1997). Problems regarding type locality and labelling of specimens representing Lycaenidae taxa described were documented in Prieto et al. (2016) or Benyamini et al. (2020). The case of $P$. patagonaevaga underlines again that all these problems are real and researchers working with Neotropical lycaenid butterflies has to be prepared to face them.

Another nomen nudum. As a closing remark we mention the nominal species Penaincisalia planuma Johnson, 1992, which was considered also as nomen dubium and transferred to Polyommatinae by Robbins (2004a). On the basis of available documentation it seems that this taxon is also a chimera composed from the same two species that constitute $P$. patagonaevaga: the forewings are Orthomiella, the hindwings are Penaincisalia (cf. Fig. 2). This hypothesis can be falsified or verified only via the examination of the $P$. planuma holotype which hitherto is considered to be lost.

Acknowledgements - We are indebted to $\mathrm{Mr}$ Alfredo Ugarte for his successful efforts to locate Penaincisalia patagonaevaga holotype in the collection of Pedro Vidal (ex coll. Luis Peña) - both Santiago, Chile. We express our sincere thanks to $\mathrm{Mr}$ Gergely Katona (Budapest), who composed the figure plates.

\section{REFERENCES}

BÁlint, Zs., KAtonA, G. \& Kertész, K. (2019): A new species of Penaincisalia (Lepidoptera: Lycaenidae) from Peru. Opuscula Zoologica Budapest, 50(2): 137-144. doi: 10.18348/opzool.2019.2.137

BÁlint, ZS. \& WoJTusiaK, J. (2006): Contributions to the knowledge of Neotropical Lycaenidae: Notes on Thecloxurina with the descriptions of three new species (Lepidoptera: Theclinae: Eumaeini). Genus, 17(4): 585-600. Euameini

Benyamini, D., Ugarte, A. \& BÁlint , Zs. (2020): An updated list of the butterflies of Chile (Lepidoptera, Papilionoidea and Hesperioidea) including distribution, flight period, conservation status and comments on biology. Part III/1, subfamily Polyommatinae (Lycaneidae) with descriptions of three new species of Pseudolucia. Boletín del Museo Nacional de Historia Natural, Chile, 68(1-2): 131181.

D’ABrerA, B. (1986): Butterflies of the Oriental Region. Part II. Lycaenidae \& Riodinidae. Hill Hosue, Melbourne, Australia, i-xv, p. 535-672.

D'ABrerA, B. (1995): Butterflies of the Neoptropical Region. Part VII. Lycaenidae. Hill Hosue, Melbourne, Australia, i-xi, p. 1099-1270.

INTERNATIONAL CODE OF ZOOLOGICAL NOMENCLATURE (1999): International Code of Zoological Nomenclature. Fourth edition. The International Trust for Zoological Nomenclature, London, United Kingdom.

JoHnson, K. (1990): Penaincisalia, a new genus of "elfin"-like butterflies from the high Andes (Lepidoptera: Lycaenidae). Pan-Pacific Entomologist, 66(2): 97-125, 10 figs.

JOHNSON, K. (1992): Genera and species of the Neotropical "elfin"-like hairstreak butterflies (Lepidoptera, Lycaenidae, Theclinae). Reports of the Museum of Natural History, University of Wisconsin (Stevens Point), 22(1): 1-135, 205 figs.; (2): $136-279,241+2$ figs.

PEÑA, L.E. \& UGARTE, A. J. (1997): Las mariposas de Chile. The butterflies of Chile. Santiago de Chile, Editorial Universitaria. 359 pp, figs., maps.

PRIETO, C. (2008): Taxonomía, Biogeographía y Relaciones Filogenéticas del Género Alto-Andino Penaincisalia Johsnon (Lepidoptera: Lycaenidae: Eumaeini). Tesis Doctoral. Universisad de Alicante, Alicante, 268 pp.

Prieto, C., Grishin, N.G., HAUSMANN A. \& LoRENCBRUDECKA, J. (2016): The Penaincisalia amatista species-group (Lepidoptera: Lycaenidae, Eumaeini) in Colombia, insights from mtDNA barcodes and the description of a new species. Systematics and Biodiversity, 14(2): 171-183. doi: $\underline{10.1080 / 14772000.2015 .1112314}$ 
ROBBINS, R.K. (2004a): Introduction to the checklist of Euameini, pp. xxiv-xxx. In. LAMAS, G. (Ed.) Checklist: Part 4A. Hesperioidea - Papilionoidea. In. HEPPNER, J.B. (Ed.) Atlas of Neotropical Lepidoptera. Volume 5A. Gainesville, Association for Tropical Lepidoptera; Scientific Publishers.

RoBBINS, R.K. (2004b): Lycaenidae. Theclinae. Tribe Eumaeini, pp. 118-137. In. LAMAS, G. (Ed.)
Checklist: Part 4A. Hesperioidea - Papilionoidea. In. HEPPNER, J.B. (Ed.), Atlas of Neotropical Lepidoptera. Volume 5 A. Gainesville, Association for Tropical Lepidoptera; Scientific Publishers.

RoBBInS, R.K. \& LAMAS, G. (2002): Nomenclatural changes in the Neotropical Eumaeini (Lepidoptera, Lycaenidae, Theclinae). Revista brasileira de Zoologia, 19(Suplemento 1): 197-214, 24 figs. 